\title{
Empirical Study on Reasons of Industrial Sickness- With Reference To Jammu \& Kashmir Industries Ltd.
}

\author{
Fayza Chowdhary \\ Department. Of Commerce,Universityof Jammu,India
}

\begin{abstract}
The researcher did an empirical study to find out the opinion of the employees of Jammu \& Kashmir Industries Ltd, $J \& K$ for declaring it as a sick industry. The Researcher determined the reasons after taking the opinion from the employees of Jammu \& Kashmir Industries Ltd, $J \& K$. The objectives on which the researcher will conduct the study are: 1) To study the reasons due to which Jammu Kashmir industries Ltd. became sick industry. 2) Understanding the employees views about the most important reason for Jammu \& Kashmir Industries Ltd, $J \& K$ becoming sick.3). To frame a suitable revival strategy so as to protect the employment of the masses .and 4) Safeguard the state wealth \& resources. The researcher tabulated the data and presented the data in the form of table and pie-chart. Thereafter the researcher discussed the reasons in detail. After studying the reason and analyzing them the researcher concluded that every reason given by the employee is responsible for declaring Jатти \& Kashmir Industries Ltd. as sick industry.
\end{abstract}

Keywords: Jaтmи Kashmir Industries Ltd, Industrial Sickness, Financial Reasons and Technological Changes ,revival, managerial inability, obsolete technology.

\section{Introduction}

Closures of Public Sector Undertakings and corporate failures resulting in bankruptcies have become a normal feature in the emerging market economies the world over (Slatter, 1984; Kharbanda and Stallworthy, 1985). Growing competition and the ever changing international economic environment often lead to high incidence of corporate failures in developed market economies. However, these economies have the resilience to absorb the economic disturbances brought about by the closure of industrial units. In recent years, industrial sickness in India has reached alarming proportions. An industrial unit is considered sick when its financial position is not satisfactory and it becomes worse year after year. It incurs losses and its capital reserves may be stretched out in course of time. When its current liabilities are more than current assets, the organization may not be in a position to pay its liabilities. The increasing trend in industrial sickness touching all types of units including small, medium and large-scale industrial sectors is of considerable concern. The problem is assuming titanic proportion and may have added repercussions in a country like India which cannot afford unemployment and loss of production. J\&K is a terror victim state since years and which lost its valuable resources event after event, but still the Government of the state chalked out many strategies to bring the life into the people of the state. J\&K Industries Limited, a State Owned Company incorporated in October, 1963, having authorized share capital of Rs.20.00 Crores, was established. The main objective/functions of the company as per its Memorandum and Articles of Association aims to run, manufacture and administer the State Industrial Undertaking in a manner that would ensure their economical working. The Industry deals with the production of Processing and manufacturing of Textiles, Knitwear's / Joisery, Joinery and Furniture products as well as Silk (Plain and Printed) fabrics, besides Rosin and Turpentine. Arranging raw materials for production of all such products and marketing thereof.

\section{Criteria for Identification of Sick Units}

The Reserve Bank of India identifies sick industrial units on the basis of a mix of criteria including continued cash losses, imbalances in the financial structure, and deterioration in liquidity. "A unit may be considered sick if it has incurred cash losses for one year and, in the judgment of the Bank (RBI), it is likely to continue to incur cash losses for the current year as well as the following year and the unit has an imbalance in its financial structure such as current ratio of less than 1:1 and worsening debt equity ratio" (RBI, 1978).Term lending institutions identify sickness on the following criteria:

$\square$ Continuous defaults in meeting four consecutive halfyearly installments of interest or principal of institutional loans

Continuous cash losses for a period of two years or continued erosion in the net worth by 50 per cent or more Mounting arrears on account of statutory or other liabilities for a period of one or two years (Bidani andMitra, 1983).

The most stringent definition is given in the Sick Industrial Companies (Special Provisions) Act of 1985, which defined a sick unit as "An industrial company (being a company registered for not less than seven 
years), which has at the end of any financial year accumulated losses equal to or exceeding its entire net worth and has also suffered cash losses in such financial year and the financial year immediately preceding such financial year,"

\section{Stages of Industrial Sickness}

An individual unit passes through several stages before it becomes sick. The knowledge about the various stages of sickness is very essential for taking corrective and appropriate measures in appropriate time. The different stages of sickness along with the determinants which identify these stages as per the guidelines of Reserve Bank of India (RBI) are given below:-

Normal Unit - A normal unit is characterized by the efficient functioning of its functional areas like production, marketing, finance and personnel. In other words, a unit can be called healthy or in a normal state (NS) when it is earning profits, the current ratio is more than one, net worth is positive and debt-equity ratio is good.

Tending Towards Sickness- At this stage a unit shows certain initial aberration in any of its functional areas. In other words, the unit faces some environmental constraints. At this time, the unit is said to be tending towards sickness (TS). The distinctive features of this stage are decline in profit in the last year as compared to the previous year and loss estimated in the current year.

Incipient Sickness - The continuation of the deterioration in the functional areas of the unit, results in the actual setting in of industrial sickness. This stage is termed as incipient sickness (IS). At this stage, the unit incurs cash losses but imbalance in the financial structure may not be apparent

About Jammu Kashmir Industries Limited ,J\&K is a Company registered under the Companies Act, 1956 and was incorporated on the 03.10.1963. This Corporation is wholly owned J\&K Government undertaking . The Shared Capital of the Corporation is Rs.20.00 Crores and paid up capital is Rs.16.26 Crores. This Corporation was set up with the main object of promoting local \& traditional art of the state dealing with wood work, woolen ,kashmiri silk ,kashmiri carved furniture, Rosin \&Turpentine industry in the State of J\&K.

The Jammu \& Kashmir Industries Ltd is presently engaged in.

\section{Silk Works}

The J\&K State has a traditional base in Sericulture. The Production of Reeling Cocoons has declined considerably in the State resulting in closure of two supplementary silk reeling units, Govt. Silk Filatures, Rambagh, Srinagar and Govt. Silk Factory, Jammu, thereby reducing production efficiency of Silk Weaving Factory, Rajbagh, Srinagar. The machinery is very old and there are proposals of its modernization/reengineering under consideration with reference to the Project report which was for prepared from M/S Tecsok, Karnataka with financial assistance from the Ministry of Textiles, Govt. of India which envisaged investment of Rs.532.35 Lakhs for re-engineering of the two Reeling units and up gradation of machinery in Silk Weaving Factory with augmentation of semi-automatic power looms with Dobby etc. The factory has potential to manufactured silk products in different qualities particularly Chinon, Chiffon, IAL, Charmous which is marketed in plain and prints as well.

\section{Wool Works}

Carpet, Crewel, Tweed and Blanket Yarns Worsted Knitting years, Woolen/Worsted fabrics for civilian including uniform cloth for Police, Forest, Fire Services, Medical and other Department, to meet the requirements of raw material of local Shawl Industry in the State.

\section{Wood works}

In Govt. Joinery Mills, Pampore Kashmir and Bari-Brahmana, Jammu our designers are also engaged in manufacturing of Khatumband ceiling Kashmir is known for its distinctive crafts, one of which is the woodcraft. History of woodcraft in Kashmir spans over ten centuries. Woodwork is not merely a functional craft it is decorative as well. It is believable that this distinctive craft has come from Iran as the Iran link in this craft still exists. Even today different types of Khatumband are known by Persian names, he observes. Khatumband has variety to look marvelous in design, JKI have different types of Khatumband design like Moje, Moje Lehar, Teen Bakshish, Chaar Bakshish, Charr Gul, Panch Murabba, Sheesh Gul, Dus Baraan, Dehwaz Deh Girid and many more. Many buildings in and outside Kashmir can be seen having this unique type of ceiling. We have even designed the ceiling of Military Offices at Badambagh, Srinagar and Military Office in Ladakh as well. Visitors from different places visit at Govt. Joinery Mills, Pampore and come to know that the beautiful 
Khatumband ceiling which they see in house boats or in hotels is hand-made they come to us and offer is big assignments. It is also evident that these eminent craftsman not only design ceilings of houses, but ceilings of different shrines, mosques, houseboats and some hotels in Kashmir are the evident examples of the carving skill attained by these craftsmen.

One will be amazed to see the beautiful Khatumband design at the holy shrine, Khankahi Moulla, in Srinagar. With the increase in modernization, people love to make their houses and offices more beautiful and attractive and Khatumband helps them to change their dreams into reality. Today people also like to design the walls of their houses or offices by Khatumband.

The Plant has capacity to produce about 3 Lakh meters of fabric (product-mix) annually subject to availability of flow of raw material having source outside the State besides critical spare parts as the plant is equipped with sensitive machinery.

Besides, the Corporation also provides employment to the masses of the state. Already numbers of people working in the units of Jammu \& Kashmir Industries Ltd. have lost their employment due to the sickness of the units of these industries thus putting a burden on the Govt. of the state. Jammu \& Kashmir Industries Ltd. is a Public Sector undertaking of the J\&K Government. Therefore the researcher has selected Jammu \& Kashmir Industries ltd. for the study.

\section{Objectives Of The Study}

The researcher will study about the reasons why Jammu \& Kashmir Industries Ltd became sick industry. Therefore considering the study the researcher will work on the following objectives:-

2.1-To study the reasons due to which Jammu \& Kashmir Industries Ltd became sick industry

.2.2-Understanding the employee views about the most important reason for Jammu \& Kashmir Industries Ltd. becoming sick.

2.3-To frame a suitable revival strategy so as to protect the employment of the masses .and

2.4- Safeguard the state wealth \& resources.

\subsection{Study Area}

\section{Material And Method}

The area of conducting this study is Jammu \& Kashmir Industries Ltd, J\&K. The study is specific to Jammu \& Kashmir Industries Ltd. The researchers will determine the reasons of sickness and will study them to meet out the objectives of the study.

\subsection{Sample Method and Sample Size}

As the study is based upon Jammu \& Kashmir Industries Ltd. The sample size is small. The researchers will collect the data from 400 respondents who are the employees of Jammu \& Kashmir Industries Ltd. India.

\subsection{Data Collection Procedure}

The data is collected by distributing the questionnaire among the 400 employees of the industry. The respondents from Jammu \& Kashmir Industries Ltd. India in the state Jammu \& Kashmir. And where the response rate was $89 \%$. The researcher with the help of the selected sample size can know their opinion concerning the reasons of sickness of Jammu \& Kashmir Industries Ltd. India.

\subsection{Analytical Technique}

Tabulated data was analyzed with the help of simple percentage to know the highly most influencing reason for sickness of Jammu \& Kashmir Industries Ltd.

From the research carried out it was found that the Jammu \& Kashmir Industries Ltd have undergone all the above stages of industrial sickness. The researcher identified that there are various reasons that led the Jammu \& Kashmir Industries Ltd to sickness and thereafter closure of many other units of the Jammu \& Kashmir industries and now only 4 units of the industry are running that too on the verge of closure. The few of the problems that researcher identified after analyzing the questionnaires filled in by the employees of the industry:-

- Corporate planning failure.-The ill conceptualized plan, delay in action, inability to frame the modern, achievable goals, ill functional policies are responsible for the sickness of the industry. 
- Production Problems-Underutilized plants, lack of product mix, defective production, availability of the raw materials \& other consumables is another reason for the sickness of the industry.

- Financial Barriers- Finance is the most important constraint in running any organization. It is also one of the major reasons or Closure of any industry. To operate any industry finance is most important consideration. Every industry needs finance to manage their day-to-day operations such as purchasing raw materials, salary pay outs, purchasing goods for office use etc. If finance is not arranged properly the industry may lead to closure. Therefore finance is most important reason responsible for sickness of any industry.

- Managerial Inability-Sometimes it is found that managers are not capable of managing the organizational activities. This may be due to various reasons such as inadequate work knowledge, uninteresting job profile or irrelevant education match with the job profile. Therefore if these sorts of experiments are done in the industry they may face the closure.

- Obsolete Technology-Technological changes also lead the industries to sickness, this happens when the proper adaptation of technology is not done. That is industry follows the old technology in production or any other related work. Therefore change in technology is also a considerable reason for industrial sickness.

- Marketing Related Problems-Produced goods or products are sold in the market. If the product is not marketed properly and supply is not proper there is possibility of customer switch to substitute product. If this issue of supply is not resolved quickly the industries may loose their customers and it can be the major reason for its sickness.

- Human Resource Problems: Lack of skilled labors ,deficiency among the technical staff, delay in the practicing of the modern HR Practices etc .If any of the implication is neglected it may lead to sickness.

\begin{tabular}{|l|l|l|l|l|}
\hline Factors & $\begin{array}{l}\text { Respond of } \\
\text { Employees of } \\
\text { Unit- } \\
\text { I(Rajbagh) }\end{array}$ & $\begin{array}{l}\text { Respond of } \\
\text { Employees of } \\
\text { Unit- } \\
\text { II(Pampore) }\end{array}$ & $\begin{array}{l}\text { Respond of } \\
\text { Employees of } \\
\text { Unit- } \\
\text { III(Bemina) }\end{array}$ & $\begin{array}{l}\text { Respond of } \\
\text { Employees of } \\
\text { Unit-IV(Bari } \\
\text { Bramana) }\end{array}$ \\
\hline $\begin{array}{l}\text { Financial } \\
\text { Factor }\end{array}$ & $87 \%$ & $92 \%$ & $79 \%$ & $94 \%$ \\
\hline $\begin{array}{l}\text { Production } \\
\text { Factor }\end{array}$ & $68 \%$ & $65 \%$ & $74 \%$ & $57 \%$ \\
\hline $\begin{array}{l}\text { Managerial } \\
\text { Inability }\end{array}$ & $45 \%$ & $68 \%$ & $78 \%$ & $85 \%$ \\
\hline $\begin{array}{l}\text { Obsolete } \\
\text { Technology }\end{array}$ & $43 \%$ & $54 \%$ & $26 \%$ & $65 \%$ \\
\hline $\begin{array}{l}\text { Marketing } \\
\text { Problems }\end{array}$ & $25 \%$ & $75 \%$ & $78 \%$ & $89 \%$ \\
\hline $\begin{array}{l}\text { Human } \\
\text { Resource } \\
\text { Problem }\end{array}$ & $39 \%$ & $59 \%$ & $54 \%$ & $76 \%$ \\
\hline $\begin{array}{l}\text { Corporate } \\
\text { Planning } \\
\text { Problem }\end{array}$ & $45 \%$ & $78 \%$ & $83 \%$ & $95 \%$ \\
\hline
\end{tabular}

\section{Findings And Conclusions}

The researcher considered the major reasons that lead to industrial sickness. The researcher found that financial reasons are the most important reason considered by the respondents of industrial sickness and another chief reason for the sickness of the industry is the managerial inability i.e. not able to cope up with the dynamism occurring in the modern day markets. Rest factors which influence the sickness in the industry are Marketing problems and the corporate planning problems. However the impact of obsolete technology is least on these units in comparison to the other factors. The difference in the opinion exists between the employees of these units in some of the aspects like Marketing Problems, Managerial inability, HR Problems. Changes acts as an important reason for sickness. The researcher also concluded that there exist some variation between the views and opinion of employees of these units regarding the reason of sickness. 
Thus from the all above it is very clear that the reason for industrial sickness in this PSU is mainly due to the internal failure thus a suitable revival strategy is to bring in the desired changes in the managerial ability \& the Human Resources of the industry. So it is very clear that in all the four units the response is quite similar, thus we need to adopt similar kind of revival strategies for all the units to come back again.

It was suggested that the EDIs of the state should actively participate in training of the employees of sick units periodically. The development corporations, financial institutions should make efforts in alarming the units becoming sick. The study is limited to single public sector undertakings residing in J\&K only. The respondents seem to be unwilling due to lack of interest, negligence, communication problems. The element of subjectivity in interpretation cannot be ruled out in eliciting requisite information.

From the research carried out it was also revealed that the PSU's faces number of problems but the factor behind less sales of these units were related to marketing inefficiencies. The importance of innovative marketing strategies in bringing about successful turnarounds has been highlighted by several researchers. The marketing oriented business is customer focused, and generates and disseminates marketing intelligence that is widely used throughout the firms. Such firms are able to sense and respond to market force with greater precision than inward looking rivals so we can say a good action again is required by the managerial staff for the revival.

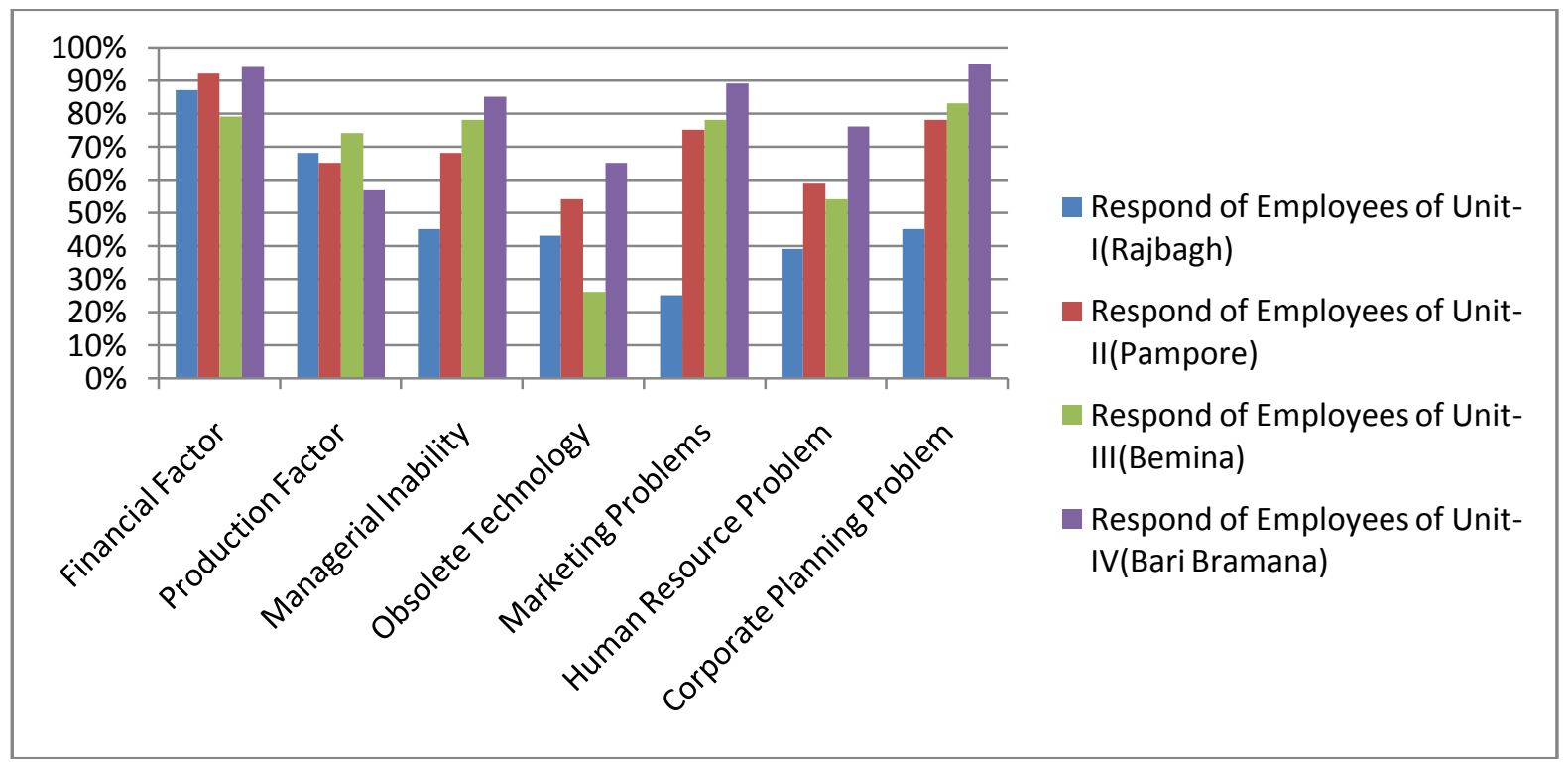

\section{References}

[1] Bidani, S N and Mitra, P K (1983). Industrial Sickness: Identification and Rehabilitation. New Delhi: mission Books

[2] Jhunjhunwala B, 2008, Business Statistics- A Self Study Textbook, S. Chand and Company Ltd, New Delhi.. Kharbanda, O P and Stallworthy, E A (1985). Corporate Failure: Prediction, Panacea and Prevention. London: McGraw-Hill.

[3] Nayak S S \& Misra R.N (September- October 2006), Sickness in Small-Scale Industrial Units and Its Revival, Orissa Review, Orissa.

[4] RBI (1978). Trend and Progress of Banking in India, 1977- 78.

[5] Sick Industrial Companies (Special Provisions) Act (1985), Government of India

[6] Slatter, S (1984). Corporate Recovery: Successful Turnaround Strategies and their Implications.Harmondsworth: Penguin Books. http://www.uplclko.in/introduction.asp

[7] Heggde,Githa S. and panikar, Ashok (2011)Internal and external causes of sickness, Vikalpa

[8] Rosemarry K. Abraham and M. Omkarnath (2006),Trajectories of sickness, Vikalpa

[9] Garg,Sudhir(2012),Industrial sickness, Institute of Chartered accountants of India.

[10] Hegde, Manjunath (1982), “Western and Indian model of turnaround management", Indian Journal of Research, Volume 7, issue 4, pp. 289-304.

[11] Walter,Norbert(2009), "Understanding the financial crises :roots and developments in the financial sector" „European view(2009), DOI 10.1007/s 12290-009-0066-x 11, pp. 97-103.

[12] Yadav \& Srivastava (2010), "Industrial sickness in small scale industry sector-causes and preventive measures", Indian Journal of Research, Volume 5, issue 5, pp.1-5.

[13] Manimala \& Panichar(2011), "Successful Turnarounds: The Role of Appropriate Entrepreneurial strategies, IIMB , Working paper no. 337,pp. 1-29

[14] Prasad,V(2006), "Role of HR in corporate turnaround" HRM Review, July, pp11-29. 
Questionnaire For Assessing The Industrial Sickness In Jammu \& Kashmir Industries Ltd. NOTE: You are requested to tick $(\square)$ the relevant box and fill in the relevant blanks. The information so collected would be used only for research purpose.

\section{PERSONAL INFORMATION}

1 Name \& Address of the employee

2 Place of work

3 Designation:

4 Department : Production $\mathrm{Fi} \square \mathrm{ce}$ $\mathrm{M} \square$ eting Ot $\square$

5 Gender : Male

Female
6 Age:
1- Below 25
2- Between 25 to 45
3- 45 above

7 Educational qualification: Illiterate/ Primary/ Middle/ Secondary/ Graduate/ any other 8. Year of joining the organization

\section{OTHER INFORMATION}

Please tick the relevant box which describes the statement. Here 1=Strongly Disagree; 2=Disagree; 3= neither Agree nor Disagree; 4=Agree; 5=Strongly Agree

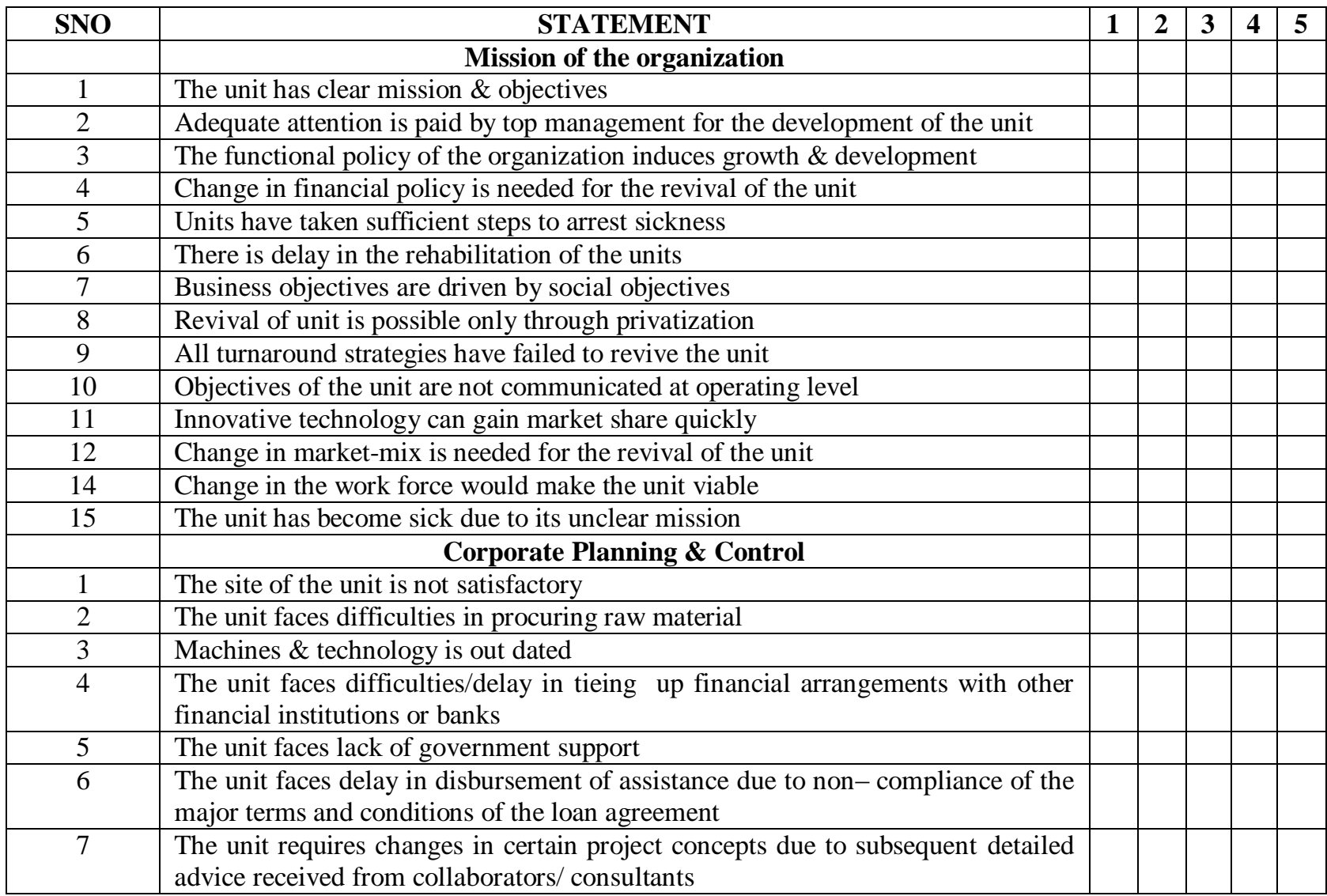




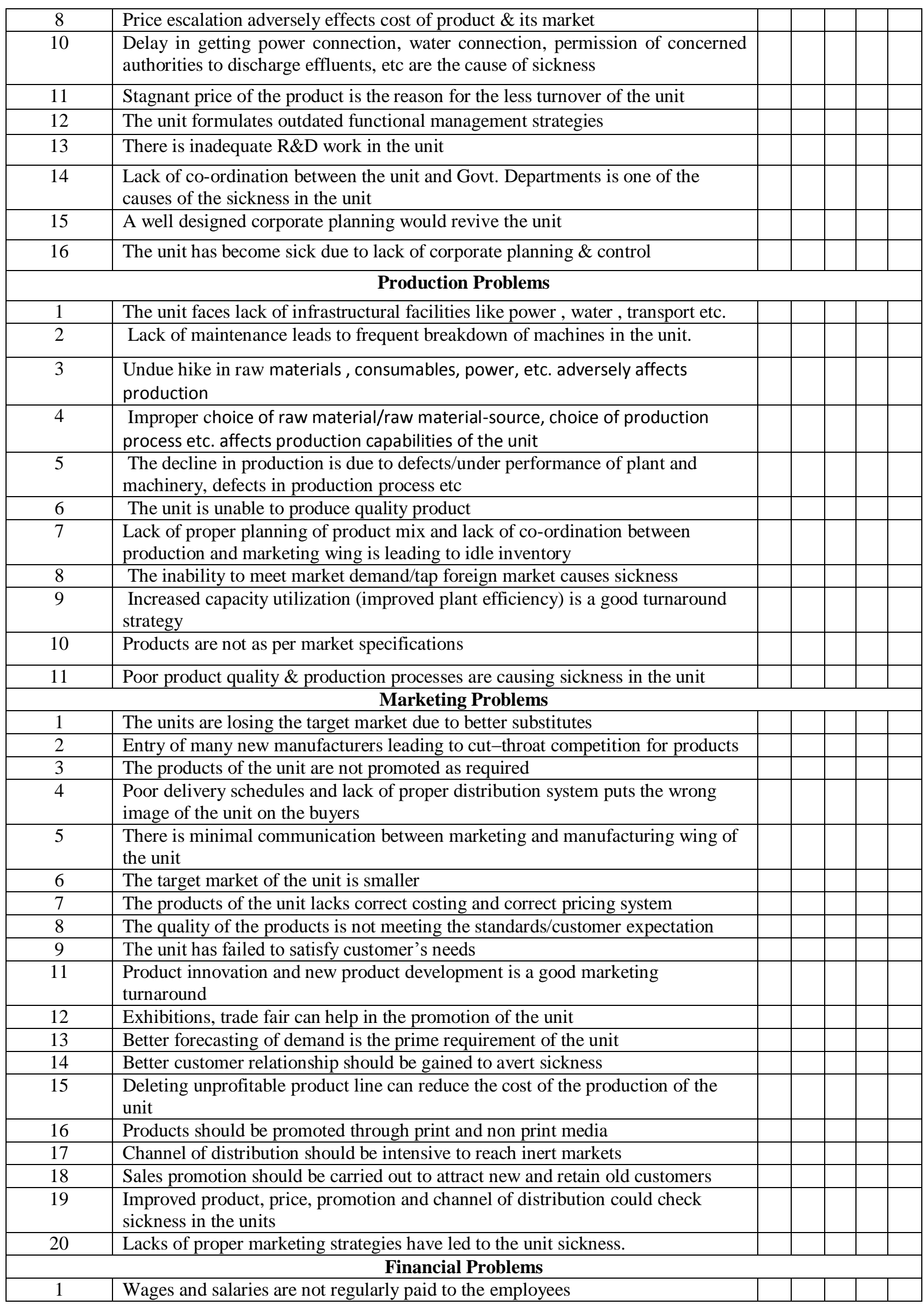




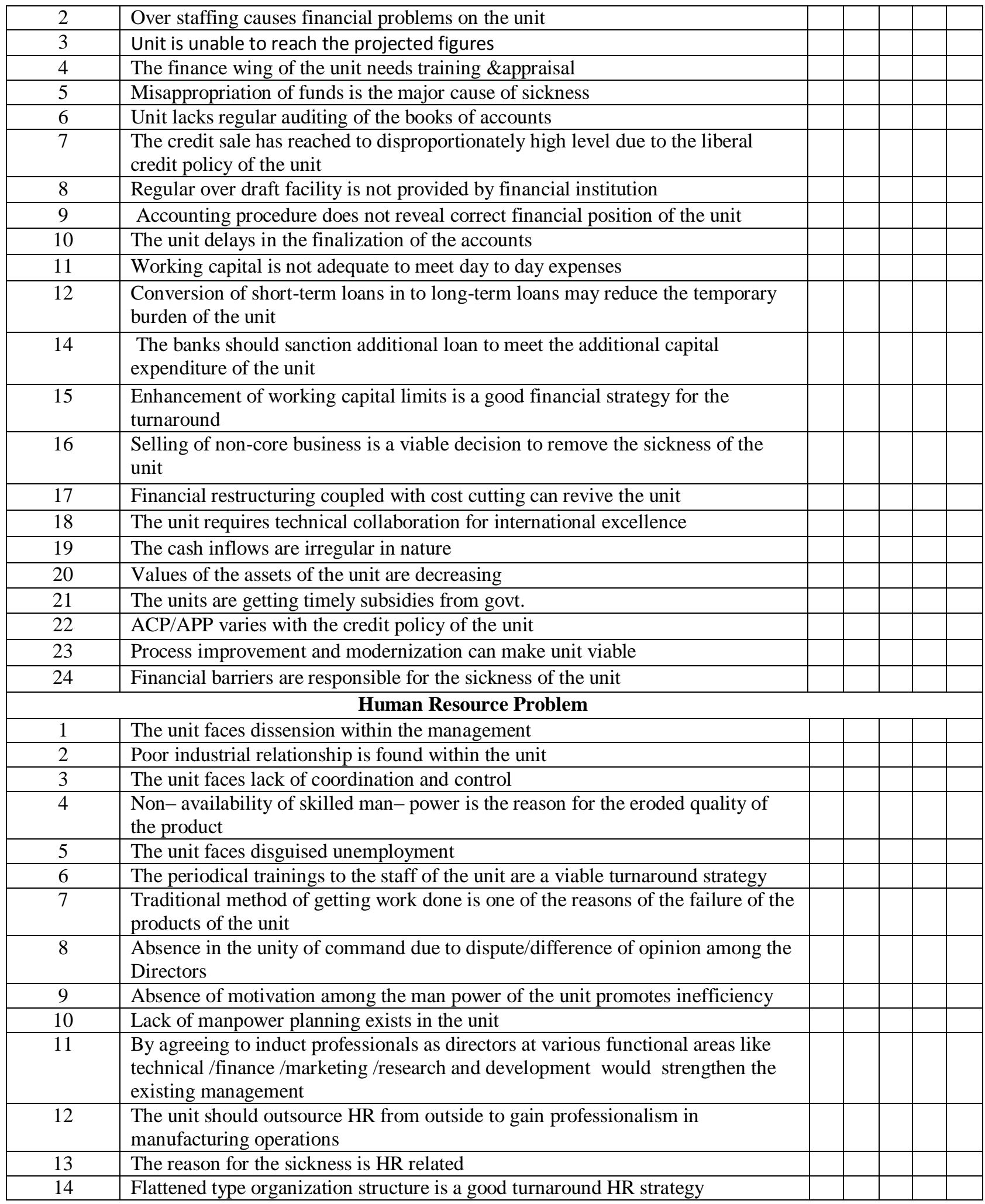

